\title{
DZIEŃ PAŃSKI W NAUCZANIU ŚW. CEZAREGO Z ARLES W ŚWIETLE STUDIUM JEGO KAZAŃ DO LUDU
}

\begin{abstract}
Sobór Watykański II w Konstytucji o liturgii świętej stwierdza:
„Zgodnie z tradycją apostolską, która wywodzi się od samego dnia zmartwychwstania Chrystusa, misterium paschalne Kościół obchodzi co osiem dni, w dniu, który słusznie nazywany jest dniem Pańskim albo niedzielą. W tym bowiem dniu wierni powinni schodzić się razem dla słuchania słowa Bożego i uczestniczenia w Eucharystii, aby tak wspominać mękę, zmartwychwstanie i chwałę Pana Jezusa i składać dziękczynienie Bogu, który ich «odrodził przez zmartwychwstanie Jezusa Chrystusa ku nadziei żywej» (1P 1, 3). Niedziela jest zatem najstarszym i pierwszym dniem świątecznym, który należy tak przedstawić i wpoić w pobożność wiernych, aby stał się również dniem radości i odpoczynku od pracy. Ponieważ niedziela jest podstawą i rdzeniem całego roku liturgicznego, nie należy jej przesłaniać innymi obchodami, jeżeli nie są rzeczywiście bardzo ważne"l.
\end{abstract}

Temat celebrowania dnia Pańskiego jest ważny i poświęcano mu wiele uwagi na przestrzeni wieków ${ }^{2}$. Ponieważ nie ma jednak osobnego studium ${ }^{3}$, niniejszy artykuł jest próbą spojrzenia na dzień Pański oczyma św. Cezarego z $\mathrm{Arles}^{4}$, na

* Dr hab. Józef Pochwat MS - absolwent patrologii w Instytucie Teologii Dogmatycznej na Wydziale Teologicznym Uniwersytetu Papieskiego Jana Pawła II w Krakowie; e-mail: jotpe67@wp.pl.

${ }^{1}$ Sobór Watykański II, Konstytucja o liturgii świętej „Sacrosanctum Concilium” 106, w: Sobór Watykański II, Konstytucje, Dekrety, Deklaracje, tekst polski, red. J. Groblicki - E. Florkowski, Poznań 1968², 63-64.

${ }^{2}$ Por. H. Pietras, Dzień święty. Antologia tekstów patrystycznych o świętowaniu niedzieli, Kraków 1992. Na wagę dnia Pańskiego zwróciła uwagę Najświętsza Maryja Panna w swym Orędziu w La Salette w dniu 19 września 1846 r., zob. np. J. Pochwat, Zgłębiając Orędzie Maryi z La Salette, La Salette - Rzeszów 2002 (mps); tenże, Drogi Krzyżowe z La Salette, Kraków 2005; tenże, Spotkanie z Maryja w La Salette, Kraków 2010; tenże, Bąd́ pozdrowiona płaczaca Matko, Kraków 2010; tenże, Teksty liturgiczne o Najśw. Maryi Pannie z La Salette, Poznań - Kraków 2012.

${ }^{3}$ Istnieje wybór kazań dotyczących tego tematu w: A. Żurek, Św. Cezary z Arles, OŻ 17, Kraków 2002, 143-164 oraz H. Pietras, Dzień święty. Antologia tekstów patrystycznych o świętowaniu niedzieli, Kraków 1992, 85 i 107-109.

${ }^{4}$ Odnośnie do danych biograficznych św. Cezarego z Arles zob. Cyprianus - Firminus - Viventius - Messianus - Stephanus, Vita S. Caesarii, ed. G. Morin, w: Sancti Caesarii Episcopi Arelatensis, Opera omnia, II: Opera varia: Epistulae, Concilia, Regulae monasticae, Opuscula theologica, 
podstawie analizy merytorycznej zbioru jego pierwszych 80 kazań wydanych jako Kazania do ludus.

Problematyka zostanie ujęta w pięciu punktach: 1. Społeczny wymiar uczęszczania do kościoła, 2. Zachowanie wiernych w kościele, 3. Postawa chrześcijanina a poganina, 4. Centrum niedzieli - Eucharystia, 5. Godne przyjmowanie Komunii św.

1. Społeczny wymiar uczęszczania do kościoła. Chrześcijanin ma się odróżniać od reszty społeczeństwa świętowaniem niedzieli, poprzez uczestnictwo we Mszy świętej.

„W każdą niedzielę - jako dzień Pański - przychodźcie do kościoła. Jeżeli bowiem nieszczęśliwi Żydzi obchodzą z taką pobożnością szabat, że w nim nie wykonują żadnych prac ziemskich, o ileż bardziej chrześcijanie powinni w dzień Pański oddawać się jedynie Bogu i dla zbawienia duszy swojej w kościele się schodzić? A kiedy zbieracie się w kościele, módlcie się za wasze grzechy, nie wszczynajcie kłótni, nie ważcie się wzniecać sprzeczek, ani wywoływać skandali. Kto przybywając do kościoła czyniłby to, tam się rani, gdzie kłócąc się, mógł się uzdrowić przez modlitwę".

Cezary poucza chrześcijan o obowiązku systematycznego uczęszczania w niedzielę do kościoła. Mają to czynić po to, aby oddawać Bogu cześć. W kościele chrześcijanin ma się zajmować modlitwą, ma być skupiony, jego zachowanie ma być godne spotkania z Bogiem. Biskup Cezary poucza także wiernych o właściwej motywacji uczęszczania do kościoła. Chodzi o to, aby otwierać się na Boga, który ma moc ożywczą. Regularnie uczęszczający do kościoła pokazuje swoją postawą, że traktuje Boga jako ożywiające źródło wody?

Wierni obecni w kościele swoją obecnością sprawiają Cezaremu radość. Biskup Arles zwraca uwagę na to, aby na nabożeństwa przychodzono punktualnie, a nawet przed rozpoczęciem Mszy św., aby trwać na modlitwie.

„Cieszę się, bracia umiłowani, i dziękuję Bogu, widząc was spieszących wiernie do kościoła, aby słuchać czytań Bożych; ale jeśli chcecie, aby wasz

Testamentum. Vita ab eius familiaribus conscripta, Maretioli 1942, 296-345, tłum. A. Strzelecka: Cyprian, Firmin, Wiwencjusz, Messjan, Stefan, Żywot Cezarego z Arles, POK 32, Poznań 2008, 7-118; zob. też: M.J. Delage, Introduction, w: Césaire d'Arles, Sermons au peuple, SCh 175, Paris 1971, 13-214; L. Gładyszewski - H. Wegner, Cezary z Arles, EK III 42-44; E. Stanula, Wstep, w: Św. Cezary z Arles, Kazania, tłum. S. Ryznar, PSP 52, Warszawa 1989, 5-15; A. Żurek, Cezary z Arles, Kraków 2003; J. Pochwat, Sprawiedliwość i miłosierdzie. Studium „Kazań do ludu” św. Cezarego z Arles, Kraków 2008, 7-24.

${ }^{5}$ Ed. M.J. Delage: Césaire d'Arles, Sermons au peuple, Introduction, traduction et notes par M.J. Delage, I-III, SCh 175, 243, 330, Paris 1971-1986, thum. S. Ryznar: Cezary z Arles, Kazania, PSP 52, Warszawa 1989 (kazania 1-55; polskie cytaty z pozostałych kazań podaję w przekładzie własnym).

${ }^{6}$ Caesarius Arelatensis, Sermo 13, 3, SCh 175, 420, thum. PSP 52, 75.

${ }^{7}$ Por. tamże 77, 4, SCh 330, 230. 
postęp i nasza radość stały się pełne, musicie to czynić wcześniej rano. Kiedy noce są tak długie, kogo żadna choroba nie zatrzymuje, nie spóźnia się do kościoła bez winy w swojej duszy".

Cezary upomina wiernych, którzy spóźniają się na wspólną modlitwę i po czytaniu słowa Bożego opuszczają wspólne zebranie. Przypomina wiernym, że kapłani dbają o to, aby modlitw nie przedłużać, uwzględniają bowiem fakt, że wielu spośród wiernych udaje się do pracy.

„Proszę, abyście ich napominali i przez waszą świętą i zbawienna radę, skłaniali do naśladowania was, tak jak to powinni czynić. Ile czasu, moi bracia, widzimy ich zajętych? Sami widzicie, że to zaledwie pół godziny; i jeszcze, aby nie pozwolić, żeby biedni i robotnicy nie spóźnili się do pracy, każdego razu, kiedy przewidziane jest kazanie, dajemy psalm 50, aby nie wychodzono z kościoła późno, ale zawsze o stałej porze"

Cezary z Arles upomina wiernych, aby nie wychodzili z kościoła przed zakończeniem Mszy św. Ma jednak wzgląd na okoliczności i dlatego wcześniej wyjść mogą osoby chore lub pełniące jakieś urzędy publiczne.

„Wciąż i na nowo proszę i równocześnie wzywam, aby nikt w dzień Pański, a zwłaszcza w większe święta, nie wychodził z kościoła przed zakończeniem sprawowania Bożych tajemnic, o ile, jak już powiedzieliśmy wcześniej, ciężka niedyspozycja lub obowiązek publiczny przeszkodzi mu w dalszym pozostaniu w kościele. Prawdę powiedziawszy, jest rzeczą bardzo przykrą, a nawet wielce bezbożną, że chrześcijanie nie mają szacunku dla dnia Pańskiego, jaki zauważa się u Żydów zachowujących szabat ${ }^{10}$. [...] W końcu, grzeszymy przeciw Bogu ciężko, jeżeli zaniedbujemy poświęcić cały dzień Pański na lekturę Pisma [Świętego] i modlitwę do Boga. Jak wielkim jest złem, jeżeli brakuje nam cierpliwości, by stać w kościele jedną lub dwie godziny, gdy sprawowane są Boże tajemnice? A jeszcze gorsze jest to, że nas upaja miłość tego świata i to do tego stopnia, iż pociąga nas żądza pożądliwości światowych i ulotne cienie próżnej i fałszywej radości, która powoduje prawdziwe cierpienia" $"$.

Za przykład świętowania dnia Pańskiego Cezary stawia chrześcijanom Żydów świętujących swój szabat. Chrześcijanin w niedzielę powinien cały dzień poświęcić lekturze Pisma Świętego i modlitwie. Jego obowiązkiem jest również uczestnictwo we Mszy św., na którą musi poświęcić jedną lub dwie godziny czasu.

${ }^{8}$ Tamże 72, 1, SCh 330, 178.

${ }^{9}$ Tamże 76, 2, SCh 330, 220.

${ }^{10}$ Por. tamże 13, 3, SCh 175 (o szacunku Żydów do szabatu). Synod w Orleanie (Concilium Aurelianense (538) can. 31, ed. C. de Clercq, CCL 148A, Turnhout 1963, 125) zezwala w niedzielę na prace gospodarskie.

${ }^{11}$ Caesarius Arelatensis, Sermo 73, 4, SCh 330, 196-198. 
Biskup Cezary porównuje uczestnictwo w uczcie Eucharystycznej do uczestnictwa w uczcie królewskiej lub w towarzystwie jakichś innych osobistości. Ubolewa nad tym, że wierni mają większy szacunek do ludzi niż do Boga, skoro ze Mszy św. wychodzą przed jej zakończeniem, podczas gdy na ucztach świeckich pozostają aż do ich zakończenia.

„Chciałbym wiedzieć, czy gdyby tacy ludzie zostali zaproszeni na ucztę przez jakiegoś króla lub też inną osobistość, to czy ośmieliliby się wyjść, zanim się zakończy. Gdyby nawet nikt ich nie zatrzymywał, to łakomstwo ich zatrzyma. Dlaczego nie wychodzimy z przyjęcia przed jego zakończeniem nawet, gdy obawiamy się, aby nie napełnić żołądka bardziej niż wypada, czy obawiamy się urazić człowieka? Dlaczego zaś szybko wychodzimy z duchowej i Bożej uczty? Boję się powiedzieć, aby przypadkiem ktoś się nie obraził, ale powiem ze względu na niebezpieczeństwo, które grozi zarówno wam, jak i mnie. Czynimy tak, dlatego, że nie zależy nam ani na pokarmie dla duszy, ani nie boimy się Boga, ani też nie szanujemy człowieka. Bogu dzięki, nie wszyscy pod tym względem są winni. Wielu jest takich, którzy z wielką skruchą nie wychodzą z kościoła przed udzieleniem błogosławieństwa, i modlą się pokornie nie tylko za siebie, ale też za innych. [...] Nie możemy i nie powinniśmy obwiniać tych, którzy ze względu na publiczne obowiązki ${ }^{12}$, albo z powodu własnej słabości nie mogą na to czekać. Niech jednak w swoim sumieniu zbadają, czy ich odciąga konieczność, czy wola"13.

Cezary stawia sprawę jasno: samo wysłuchanie słowa Bożego to zbyt mało, wierny ma pozostać w kościele do końcowego błogosławieństwa. Cezary tę powinność kładzie na sumienie każdego wierzącego człowieka.

Biskup Arles uważa, że wychodzący z kościoła przed zakończeniem Mszy św. nie rozumieją tajemnic, które na ołtarzu są sprawowane, i popełniają podwójny grzech: nie uczestniczą w tajemnicach Bożych i gardzą kapłanem, który martwi się o stan dusz takich ludzi. Przedwczesne wychodzenie z kościoła Cezary kwalifikuje jako grzech ciężki ${ }^{14}$.

Cezary dostrzega dwojakiego rodzaju przyczyny uniemożliwiające wiernym uczestnictwo we Mszy św. aż do jej zakończenia. Przyczyny, które to usprawiedliwiają - dolegliwości fizyczne, prace społeczne, i przyczyny, które tego nie usprawiedliwiają - chciwość, procesowanie się i niegodne zachowanie w kościele i jego sąsiedztwie.

${ }^{12}$ M.J. Delage (SCh 330, s. 196, nota 1) podaje, że od ogłoszenia przez cesarza Konstantyna w dniu 7 III 321 r. prawa De Feriis, zabroniono wykonywania w niedziele czynności sądowniczych. Z okazji id grudniowych w 469 r., cesarz Leon I i Antemiusz, dodali całkowity zakaz przedstawień teatralnych i walk zwierząt tego dnia. Synod w Orleanie (538), w kanonie 31 (CCL 148A, 125) zabronił pracy w polu.

${ }^{13}$ Caesarius Arelatensis, Sermo 73, 3, SCh 330, 194-196.

${ }^{14}$ Por. tamże 74, 1, SCh 330, 200; Sermo 73, 5, SCh 330, 198. 
„Różne zajęcia sprawiają, że wszyscy nie mogą pozostać w kościele: jednych trzyma ułomność ciała; innych obowiązek publiczny; innych wiąże jak pojmanych żądza. Ilu teraz na placach publicznych i w atriach bazylik zajmuje się sporami i interesami! Ilu w portykach bazylik i w zakrystiach spędza czas na oszczerstwach lub próżnych plotkach, pomiędzy którymi znajduje się zazwyczaj nie mała liczba duchownych! [...] Nie mówimy, że nie powinni się troszczyć o pożywienie i ubiór, ale prosimy, aby w przeciągu jednej lub dwóch godzin, podczas gdy czytane są czytania i sprawuje się tajemnice Boże, nie wychodzili z kościoła; i aby pracowali dla swej duszy tylko tyle, ile starają się pracować dla ciała. [...] A radzimy to na czas obecny, aby starali się na równi zabiegać o ich potrzeby: ciału niech dostarczają to, co wystarczy na tym świecie na krótki czas, a duszy tego, czego ona potrzebuje bez końca na wieki"'15.

Cezary zachęca obecnych w kościele, aby przypominali nieobecnym o konieczności uczestniczenia we Mszy św. niedzielnej i świątecznej. Wierny musi znaleźć jedną lub dwie godziny na Eucharystię, wsłuchiwanie się w czytania zaczerpnięte z Pisma Świętego i pozostawanie w kościele do zakończenia Mszy świętej.

2. Zachowanie wiernych w kościele. Klasycznym przykładem właściwego zachowania w kościele jest ewangeliczny celnik, który swoją uniżoną postawą ciała w świątyni podczas modlitwy, wykazał pokorę przed Bogiem i został przez Niego usprawiedliwiony.

„Proszę was i zachęcam, najdrożsi bracia: każdego razu, kiedy duchowni modlą się blisko ołtarza, bądź diakon zaprasza głośno do modlitwy, schylcie nie tylko serce, ale również ciało. Na wezwanie diakona: «Zegnijmy kolana», ja, który często, jak przystoi, pilnie tego słucham, widzę większą część wiernych stojących prosto, jak kolumny ${ }^{16}$, co w każdym razie nie przystoi ani nie jest na miejscu dla chrześcijan, kiedy modlimy się w kościele; gdyż to nie z naszego powodu diakon podnosi głos. [...] Dlatego jeśli komuś jakakolwiek ułomność przeszkadza uklęknąć, niech nie wstydzi się przynajmniej pochylić

\footnotetext{
${ }^{15}$ Tamże 74, 3, SCh 330, 204-206.
}

${ }^{16}$ Por. Św. Cezary z Arles, Kazania do ludu (1-80), thum. S. Ryznar - J. Pochwat, ŹMT 57, Kraków 2011, 399, nota 2: „A. Manser zasygnalizował Morinowi w Homilii 53. Sewera Antiocheńskiego, w której znajduje się zdanie bardzo bliskie do tego u Cezarego: PO 4, 42: «... Ale módlmy się ze łzami, zginając kolana do ziemi. Prośmy; błagajmy. Jestem zawstydzony i zasłaniam twarz, kiedy my kapłani jesteśmy rozciągnięci na ziemi i modlimy się, i wówczas, gdy widzę was stojących pośrodku ludu z otwartymi ustami. Diakon woła do wszystkich jednakowo, aby zgiąć kolana...». Morin wysnuł przypuszczenie, że homilie Sewera mogły być przeniesione do południowej Galii dzięki Syryjczykowi, imię Efrem nie jest użyte z powodu jego pewniejszej ortodoksyjności. Na temat obecności kupców «syryjskich» w Arles i ludności greckojęzycznej, por. Delage, Introduction, s. 127-128. Warto nadmienić, że ta aluzja liturgiczna jest jedynym punktem wspólnym między homilią Sewera i kazaniem Cezarego". 
karku i schylić głowę, rozważając, że to dzięki tej pokorze celnik otrzymał miłosierdzie Boże, [celnik], który nie śmiał wznieść oczu ku niebu, ale z głową pochyloną ku ziemi, bił się w piersi i jak surowy sędzia, biczował wewnątrz siebie grzechy [...].Trzeba się zastanowić nad przykładem faryzeusza i obawiać się, że to przez wzgląd na to, iż stał modląc się, nie zasłużył, aby być wysłuchanym"17.

Biskup Cezary uważa, że postawa ciała w kościele podczas modlitwy ma duże znaczenie. Osoby chore mogą dyspensować się od zachowania postawy stojącej, ale osoby zdrowe powinny ją zachować. A już karygodną jest - według Cezarego - postawa leżąca w kościele. Cezary dba o to, by wierni swą postawą pomagali sobie i innym w słuchaniu słowa Bożego ${ }^{18}$. Nawet gdyby kapłan był niedbały w służbie Bożej, nie usprawiedliwia to wiernych. Cezary jest przekonany o tym, że ludzie zaniedbujący klękanie i pochylanie się w czasie modlitwy są najczęściej jedynie rozplotkowanymi widzami i w kościele tak naprawdę się nie modlą ${ }^{19}$.

Biskup Arles wyraża swoją wielką radość z faktu dużej frekwencji ludzi w kościele w niedziele i święta. Ubolewa jednak nad tym, że wierni źle zachowują się w świątyni.

„Wielka to dla mnie radość, i dziękuję za to Bogu, że w świętych uroczystościach z dziecięcą pobożnością przychodzicie do kościoła. Chociaż cieszymy się z waszej pobożności, to jednak musimy się smucić z wielu takich, co idą na zatracenie. O takich mówię, co przychodząc do kościoła pragną się raczej kłócić niż modlić. Kiedy powinni w kościele uważnie słuchać czytania [słowa Bożego], oni na zewnętrz załatwiają sprawy i odważają się obrzucać różnymi obelgami. Niekiedy także, co gorsze, niektórzy zapalają się nieopanowanym gniewem, bardzo złośliwie się kłócą i ciskają na siebie wstrętne przezwiska i zarzuty o zbrodnie, niekiedy nawet napadają na siebie z pięściami i kopią butami. W rzeczywistości lepiej byłoby dla nich w ogóle nie przychodzić do kościoła, niż prowokować przeciw sobie gniew Boży złym postępowaniem"20.

Cezary uważa, że lepiej nie przychodzić do kościoła, niż swoją postawą gorszyć innych i samemu ponosić szkodę na duszy ${ }^{21}$. Za niewłaściwe podchodzenie do spraw świętych trzeba będzie zdać sprawę w dniu sądu ${ }^{22}$. Przychodzący do kościoła nie mogą wszczynać bijatyk, kłótni, czy się upijać ${ }^{23}$.

${ }^{17}$ Caesarius Arelatensis, Sermo 77, 1, SCh 330, 224-226.

${ }^{18}$ Por. tamże 78, 1, SCh 330, 238-240.

${ }^{19}$ Por. tamże 77, 5, SCh 330, 230-232.

${ }^{20}$ Tamże 55, 1, SCh 243, 466-468, PSP 52, 234-235. Por. tamże 13, 3, SCh 175, 420-422, PSP 52,75 .

${ }^{21}$ Por. tamże 55, 1, SCh 243, 466-468, PSP 52, 234-235.

${ }^{22}$ Por. tamże 50, 3, SCh 243, 468-470, PSP 52, 222.

${ }^{23}$ Por. tamże 19, 3, SCh 175, 486-488, PSP 52, 95; 55A, 3, SCh 243, 480-482, PSP 52, 240. 
Godne uczestnictwo we Mszy św., zdaniem Cezarego, polega na słuchaniu słowa Bożego w skupieniu, a także rozdawaniu jałmużny ${ }^{24}$. Biskup Arles jest przekonany, że niewłaściwe zachowanie w kościele jest służbą diabłu i nie ma nic wspólnego z dziełem Chrystusa ${ }^{25}$. Godna postawa w kościele według niego, może zasługiwać na odpuszczenie grzechów ${ }^{26}$. Cezary przypomina wiernym, że w kościele należy się modlić w skupieniu. Brak modlitwy w świątyni może być przyczyną zgorszenia dla innych, trucizną, bowiem rozmawiający w kościele przeszkadzają innym w słuchaniu słowa Bożego. Modlący się w kościele sami odnoszą duchowe korzyści i na dodatek jeszcze pomagają innym w zdobywaniu tychże wartości. Cezary jest przekonany o tym, że rozmowy w kościele obciążają grzechem sumienia osób tak postępujących ${ }^{27}$, na rozmowy bowiem jest dość czasu i okazji poza nim ${ }^{28}$.

Uczestnictwo wiernych w nabożeństwach w kościele, sprawia Cezaremu radość. Zależy mu na tym, aby fizyczna obecność w świątyni miała wpływ na ich postępowanie. Cezary przykłada również wagę do ubioru, w jakim wierni przychodzą do kościoła.

„Wielką radość sprawiła nam wasza wiara i pobożność. Gdy widzimy, że pilniej przychodzicie do kościoła, tym większą radością się unosimy i dziękujemy Bogu, że tak zechciał opanować wasze serca, że z waszego postępowania zrodziła się wielka nasza radość. Proszę was, abyście w sercu zachowali to, co ciałem ukazujecie. Wiecie, bracia, że wszyscy ludzie zachowują zwyczaj, że na święta i uroczystości przychodzą do kościoła, na ile ich stać w nowych ubraniach lub przynajmniej starannie oczyszczonych, wprost lśniących. Kto posiada starą suknię, przygotowuje sobie nową, aby do kościoła udać się pięknie ubrany. Kto ma brudne ubranie, stara się je wyprać; a kto ma podarte, usiłuje naprawić, aby ludzie nie dostrzegli nic podartego, nic zabrudzonego. Piękne i miłe jest to, co czynimy dla ciała, ale wiecie, że jest źle, jeśli tego nie czynimy dla duszy naszej. Jak więc starannie troszczysz się o twoje ciało, tak troszcz się i o duszę swoją, żeby przypadkiem nie było tak, iż twoje ciało dla oka ludzkiego jest przystrojone w lśniące szaty, a dusza twoja w oczach aniołów ukazałaby się zabrudzona. Boisz się splamienia swego ubrania.

${ }^{24}$ Por. tamże 55, 4, SCh 243, 470-472, PSP 52, 237: „Kiedy przychodzicie na uroczystości czy na Mszę, stojąc w kościele słuchajcie z radością i uważnie czytań [słowa] Bożego, a co usłyszycie, zachowujcie w pamięci i z pomocą Bożą usiłujcie wypełnić czynami. Nie chciejcie zajmować się w kościele głupimi rozmowami, nie szeptajcie do siebie nawzajem. Takich jest wiele, szczególnie niewiast, które w kościele gadają, że czytania [słowa] Bożego ani one same nie słyszą, ani innym nie pozwalają słuchać. Takie za siebie i za innych zdadzą surowo sprawę przed Panem". Zob. tamże 55A, 3, SCh 243, 480-482, PSP 52, 240; 72, 1, SCh 330, 178-180.

${ }^{25}$ Por. tamże 55A, 1, SCh 243, 476-478, PSP 52, 238.

${ }^{26}$ Por. tamże 73, 1, SCh 330, 190.

${ }^{27}$ Por. tamże 77, 6, SCh 330, 232-234.

${ }^{28}$ Por. tamże 80, 1, SCh 330, 254-256. 
Wszystko więc co znajdzie się brudnego w twojej duszy, niech zostanie obmyte łzami pokuty"29.

Ważnym jest, aby być czysto i schludnie ubranym. Ubiór ma jednak wyrażać wewnętrzną postawę człowieka: czyste ubranie - czysta dusza. Człowiek do kościoła powinien przychodzić w czystym ubraniu (wygląd zewnętrzny) i z czystym sumieniem (wygląd wewnętrzny) ${ }^{30}$.

3. Postawa chrześcijańska a pogańska. Biskup Cezary chwali wiernych za uczęszczanie do kościoła. Kościół przyrównuje do matki, a wiernych do dzieci, które do niej się garną. Jednakże martwi go, że niektórzy uprawiają kult pogański i biorą udział w odbudowywaniu świątyń pogańskich.

„Choć z tego się cieszymy, bracia najdrożsi, że was widzimy, jak chodzicie do kościoła, to jednak smucimy się i bolejemy, gdy się dowiadujemy, że niektórzy z was udają się dość często do jakichś dawnych bożków na ich nabożeństwa, jak czynią poganie bez Boga i bez łaski chrztu. Dowiedzieliśmy się, że niektórzy z was chodzą pod drzewa składać tam wota, modlić się u źródeł, brać udział w diabelskich wróżbach. [...] A co jest już gorsze, wielu takich nieszczęśników i biedaków, którzy nie tylko, że nie chcą zburzenia świątyń pogańskich, lecz także nie wstydzą się i nie boją już zburzonych odbudowywać3 ${ }^{31}$ A jeśli się ktoś znajdzie, co ze względu na Boga odważyłby się spalić, czy to drzewa święte, czy zburzyć i zniszczyć ołtarze diabelskie, złoszczą się i szaleją oraz tak rozpalają wściekłością, że zabierają się nawet do bicia tych, co z miłości do Boga usiłują burzyć świętokradzkie bożki, a może nie zawahaliby się nawet i śmiercią im zagrozićc ${ }^{32}$. Cóż robią ci nieszczęśnicy i biedacy? Porzucają światło, a pędzą w ciemność, gardzą Bogiem a wpadają diabłu w objęcia. Opuszczają życie, a idą za śmiercią. Chrystusem gardzą, a w świętokradztwo wstępują. I w jakim celu przyszli ci biedacy do kościoła? W jakim celu przyjęli sakrament chrztu świętego, jeżeli następnie mieli wrócić do świętokradzkich bożków?"33

Cezary jest przekonany, że ukłon w stronę świątyń pogańskich jest wejściem w pułapkę szatana zastawioną na wiernych, gdyż odrzucają życie, które jest w Chrystusie, a wybierają śmierć, która jest w szatanie. Kult bożków jest kultem szatana, tego chrześcijaninowi czynić nie wolno. Chodze-

${ }^{29}$ Tamże 14, 1, SCh 175, 430-432, PSP 52, 77-78.

${ }^{30}$ Por. tamże 44, 6, SCh 243, 336-338, PSP 52, 197.

${ }^{31}$ Por. Delage, Introduction, s. 139-141.

${ }^{32}$ Por. tenże, SCh 243, 446, nota 1, gdzie czytamy, że napadanie na pogańskie świątynie, czy „święte” drzewa nie zawsze było bezpieczne. Por. Vita S. Martini 13-15, ed. J. Fontaine, SCh 133, Paris 1967, 280-286.

${ }^{33}$ Caesarius Arelatensis, Sermo 53, 1, SCh 243, 444-446, PSP 52, 228. Por. tamże 13, 5, SCh 175, 426-428, PSP 52, 77. 
nie do kościoła na nic się nie przyda, jeśli człowiek będzie praktykował kulty pogańskie ${ }^{34}$.

Biskup Arles upomina chrześcijan, którzy praktykują zwyczaje pogańskie, nie zważając na zachowanie godne życia osób należących do Chrystusa. Przypomina, że chrześcijanin ma się powstrzymywać od pracy $\mathrm{w}$ niedzielę, a nie w czwartek ze względu na kult Jowisza.

„Usłyszeliśmy, że niektórych mężczyzn i kobiety do tego stopnia diabeł opętał, że w czwartki nie chodzą do pracy, a kobiety nie wykonują robótek z wełny. Wobec Boga i Jego aniołów ostrzegamy, że ktokolwiek zechce się tego trzymać, jeżeli tego tak wielkiego świętokradztwa nie naprawi przez długą i surową pokutę, zostanie potępiony tam, gdzie płonie diabeł. Ci bowiem nieszczęśnicy i biedacy, którzy ku czci Jowisza w czwartek powstrzymują się od pracy, nie wątpię, że w dzień Pański nie wstydzą się i nie boją wykonywać tychże prac. Dlatego, ktokolwiek takiego zauważy, jak najsurowiej niech go upomni, a jeżeli nie chciałby się poprawić, nie dopuszczajcie go, aby przychodził na rozmowy z wami, ani na wasze przyjęcia. Jeżeli zaś należy do waszej rodziny, nawet zbijcie go rózgami, żeby się przynajmniej chłosty cielesnej bał, jeśli nie myśli o zbawieniu swojej duszy"35.

Cezary uważa, że wobec tych, którzy nie świętują niedzieli w należyty sposób, można zastosować karę cielesną, aby ratować ich dusze.

Biskup z Alres ubolewa nad faktem prowadzenia sporów i w sposób niesprawiedliwy spraw sądowych w dni świąteczne.

„Są jeszcze inni, którzy w uroczystości narodzin świętych lub w jakiekolwiek inne święta chcą roztrząsać i wytaczać sprawy sądowe, i co gorsze, że nie dla szczerej miłości, lecz dla chciwości i żądzy. Trzeba wprawdzie prowadzić spory sądowe i rozwiązywać je sprawiedliwie, ale w inne dni i w innym czasie, nie w uroczystości świętych, gdy wszyscy ludzie powinni raczej Bogu spokojnie się oddać w modlitwie, niż spierać się różnymi kłótniami. [...] Przesłuchują strony w sprawach spornych i wydają niesprawiedliwe wyroki, przyjmują ziemskie podarki, a tracą nagrody wieczne, zdobywają pieniądze, a zaprzepaszczają życie wieczne. [...] Gdybyś sądził sprawiedliwie, gdybyś nie chciał na nieszczęście służyć twemu skąpstwu czy zbytkowi, twoja dusza pełna Boga uniosłaby się do królestwa, a skarbona bez złota zostałaby na świecie. Dlatego, bracia, proszę was i zaklinam przez Tego, którego najdroższą Krwią jesteście odkupieni, abyście postępowali sprawiedliwie we wszystkich sprawach sądowych i żebyście myśleli uważniej o zbawieniu waszej duszy"36.

\footnotetext{
${ }^{34}$ Por. tamże 54, 5, SCh 243, 458-462, PSP 52, 233.

${ }^{35}$ Tamże 13, 5, SCh 175, 426-428, PSP 52, 77.

${ }^{36}$ Tamże 55, 3, SCh 243, 468-470, PSP 52, 235-236.
} 
Cezary gani niesprawiedliwie sprawujących sądy w dni świąteczne. Wierni $\mathrm{w}$ takie dni powinni gromadzić się w kościele na modlitwę i służbę $\mathrm{Bogu}^{37}$.

Spotkanie wiernych w kościele ma owocować według Cezarego odpowiednią postawą wobec biednych w postaci udzielania im jałmużny. Niedziela ma być także dniem odwiedzin chorych i ludzi skłóconych, których należy nakłaniać do zgody.

„Skoro spotykacie się w kościele niech każdy za przywilej sobie uważa udzielanie pomocy ubogim, na ile go stać, przyjmujcie z wielką życzliwością podróżnych w waszych gościnnych domach, częstujcie tym, czym możecie, nogi im myjcie. Odwiedzajcie przed wszystkimi chorych, żyjących w niezgodzie ze wszystkich sił nawołujcie do zgody [...]. Niech nikt w sercu nie żywi nienawiści przeciw bliźniemu, ale miłość. Kto choćby jednego człowieka miał w nienawiści, nie może przed Bogiem ostać się bezpiecznie. Tak długo modlitwa jego nie będzie wysłuchana, jak długo będzie przechowywał złość w sercu swoim"38.

Sam fakt bycia chrześcijaninem wymaga od wiernego zaniechania nienawiści i życia miłością. Uczęszczający do kościoła powinien się modlić, uczciwie pracować, nie kraść, odznaczać się gościnnością, jednym słowem zachowywać Boże przykazania.

Biskup Cezary podaje kryteria, po których rozpoznać można dobrego chrześcijanina. Jest nim człowiek składający w kościele ofiary, które będą następnie ofiarowane na ołtarzu, dzielący się z potrzebującymi, gościnny, spokojny, trzeźwy, zachowujący wstrzemięźliwość płciową na kilka dni przed przyjęciem Komunii św., człowiek rozmodlony i modlitwy nauczający dzieci ${ }^{39}$.

4. Centrum niedzieli - Eucharystia. Cezary poucza wiernych, że Eucharystia jest pokarmem anielskim, pokarmem nadprzyrodzonym. Dlatego przypomina o wielkim szacunku do Niej. Odmówienie zaproszenia na Eucharystię jest odmówieniem spotkania się z zapraszającym na nią Bogiem. Wierny zatem ma poświęcić na Mszę św. jedną albo dwie godziny, aby posilić się duchowym pokarmem dusz.

„Proszę was wciąż i na nowo, chociaż nie jesteśmy godni zapraszać w imieniu Pana to przecież, gdy przychodzicie do kościoła, zapraszamy was nie na ucztę ziemską, na której podaje się pokarm ludzi, ale na ucztę niebiańską i duchową, na której ofiarowany jest chleb aniołów; nie pogardzajcie, nie lekceważcie uczty waszego Pana, aby was On nie zlekceważył w szczęśliwości swego królestwa. Powinniście się lękać ewangelicznego wyroku, na zaproszonych na ucztę weselną, którzy wzgardzili i nie przyszli, wypowiedzianego przez samego Pana, który uznał ich za niegodnych swej uczty i polecił zapro-

${ }^{37}$ Por. tamże 55A, 2, SCh 243, 478-480, PSP 52, 238-239. Zob. tamże 19, 3, SCh 175, 486-488, PSP 52, 95; 50, 2, SCh 243, 420, PSP 52, 222.

${ }^{38}$ Tamże 14, 2, SCh 175, 432-436, PSP 52, 79.

${ }^{39}$ Por. tamże 16, 2, SCh 175, 454-456, PSP 52, 86. 
sić innych (por. Mt 22, 1-10). Nie jest stratą czasu rozważenie tego, ale należy się lękać, że przez samego Pana zostali uznani za niegodnych ci, którzy z powodu przeszkód doczesnych nie chcieli przyjść"

Biskup Arles naucza, że do istoty Mszy św. należy złożenie ofiary i konsekracja darów. Wierni mają obowiązek pozostania w kościele do końca Mszy św. i brania w niej czynnego udziału. Cezary jest świadomy takiego stanu rzeczy, którym jest niezrozumienie wartości ofiary Eucharystycznej. Człowiek świadomy wielkości tajemnic Bożych dokonujących się we Mszy św., będzie w niej uczestniczył od początku do końca, w postawie rozmodlenia i pełnego szacunku skupienia.

„Proszę was bracia, abyście przyjęli naszą pokorną radę, nie tylko cierpliwie, ale i ochoczo. Jeśli będziecie pilnie uważać, poznacie, że nie wtedy jest sprawowana Msza, gdy czytane są w kościele Boże czytania, ale gdy ofiarowane są dary i konsekrowane jest Ciało oraz Krew Pana. Przecież teksty proroków, apostołów i z Ewangelii sami możecie przeczytać albo posłuchać, gdy inni czytają. Konsekracji Ciała i Krwi Chrystusa nie możecie usłyszeć ani zobaczyć nigdzie indziej jak tylko w domu Bożym. Kto zatem chce celebrować z pożytkiem dla własnej duszy w całą Mszę, winien z uniżonym ciałem i skruszonym sercem pozostać w kościele aż do odmówienia Modlitwy Pańskiej i udzielenia ludowi ${ }^{41}$ błogosławieństwa"42.

Cezary przypomina wiernym o złożeniu ofiary, która ma być konsekrowana na ołtarzu.

„Przychodząc do kościoła, złóżcie Bogu ofiarę, aby była konsekrowana na ołtarzu. Jest bowiem dużo ubogich wiernych, którzy stale przynoszą dary do ofiarowania w kościele, mimo iż prawie nie mają z czego żyć. Z gołymi rękami nigdy nie przychodzą. I przeciwnie, są bogaci, którzy ani ubogim nic nie dają, ani na ofiarę do kościoła nic nie przynoszą i nie wstydzą się przyjmować z ofiary, którą ofiarował ubogi. Dlatego raczej sąd przyjmują w Komunii (por.

1 Kor 11, 29; Jk 3, 1), niż pomoc dla siebie"43.

Biskup Arles ubolewa nad faktem, że bogaci nie chcą składać ofiar, a na domiar złego, biorą z ofiar składanych przez ludzi ubogich. Zachęca, aby do kościoła przychodzić wcześniej i przynosić dary, które są przeznaczone do konsekracji na ołtarzu ${ }^{44}$, a przyniesienie daru do ołtarza ma być równoznaczne z przebaczeniem ${ }^{45}$.

${ }^{40}$ Tamże 74, 2, SCh 330, 202-204.

${ }^{41}$ Por. Concilium Agathense (506) can 47, ed. C. Munier, CCL 148, Turnhout 1963, 212. Zob. Caesarius Arelatensis, Sermo 76, SCh 330, 218-222.

${ }^{42}$ Caesarius Arelatensis, Sermo 73, 2, SCh 330, 190-194.

${ }^{43}$ Tamże 14, 3, SCh 175, 436, PSP 52, 80.

${ }^{44}$ Por. tamże 1, 12, SCh 175, 248, PSP 52, 25.

${ }^{45}$ Por. tamże 39, 4, SCh 243, 262-264, PSP 52, 173-174. 
Cezary jest przekonany o realnej obecności Boga zarówno w słowie Bożym, jak i Komunii świętej.

„Pytam was bracia i siostry, powiedzcie mi, jak wam się wydaje, co jest ważniejsze, Słowo Boże, czy Ciało Chrystusa? Jeżeli chcecie odpowiedzieć zgodnie z prawdą, czyż nie to musicie przyznać, że Słowo Boże nie jest mniej ważne niż Ciało Chrystusa. Dlatego tak wielką troskę zachowujemy, aby wtedy, gdy udzielane jest nam Ciało Chrystusa, nic z niego nie upadło z naszych rąk na ziemię ${ }^{46}$. Taką samą troskę zachowujemy, aby słowo Boże, które jest nam podawane, nie zostało wyrwane z naszego serca, gdy myślimy lub mówimy o czymś innym, bo taką samą bowiem winę poniesie ten, kto zaniedbuje słuchania słowa Bożego, jak i ten, który dopuszcza, by przez jego niedbalstwo ciało Chrystusa upadło na ziemię"47.

Biskup Arles przypomina, że jak człowiek powinien uważać, aby nie upuścić okruszyny z Ciała Chrystusa, tak też powinien postępować, aby niczego nie uronić ze słuchania słowa Bożego. Jednakową winę ponosi wierny, który lekceważy Eucharystię i słowo Boże.

Cezary ukazał swoim wiernym Komunię świętą, jako lekarstwo dla duszy i ciała człowieka.

„Oprócz tego, kiedy ktoś zachoruje, niech uda się do kościoła i przyjmie Ciało i Krew Chrystusa i olejem pobłogosławionym przez kapłanów niech będzie namaszczony ${ }^{48}$, prosząc ich oraz diakonów, aby się nad nim modlili w imię Chrystusa. Jeżeli to chorzy zrobią, otrzymają nie tylko zdrowie ciała, ale i odpuszczenie grzechów"49.

Komunia święta i namaszczenie chorych są zdaniem Cezarego środkiem leczniczym na choroby ciała (wyzdrowienie) i duszy (odpuszczenie grzechów).

Cezary przeciwstawia Eucharystię kultom pogańskim, w których ludzie poszukiwali uleczenia z chorób. Uzdrowienia powinien człowiek szukać w sprawcy zbawienia - Chrystusie ${ }^{50}$. Zdrowy rozsądek poszukuje uzdrowienia w kościele. Nie można jednocześnie przyjmować uzdrowienia od Boga i demonów. Jedno z drugim bowiem się wyklucza i prowadzi do grzechu świętokradztwa ${ }^{51}$.

\footnotetext{
${ }^{46}$ Słowa te potwierdzają, jak się wydaje, że przynajmniej we wspólnocie Cezarego z Arles, o ile nie w całej Galii, w VI w. udzielano Komunii na rękę.

${ }^{47}$ Caesarius Arelatensis, Sermo 78, 2, SCh 330, 249.

${ }^{48}$ Por. tamże 13, 3, gdzie Cezary zachęca wiernych, aby sami siebie namaszczali. „Inunguatur” można tłumaczyć „,niech będzie namaszczony”, albo „niech namaści się”. M.J. Delage (SCh 175, 491) thumaczy ten fragment: „et soit oint par les prêtres d'huile bénite” (i niech będzie namaszczony przez kapłanów pobłogosławionym olejem), i uważa, że tekst Sermo 13, 3 został tutaj przeredagowany. Por. Delage, SCh 175, 490-491, nota 1, gdzie thumacz odsyła do dzieła A. Chavasse, Étude sur l'onction des infirmes dans l'Église latine du III e au XI' siècle, Lyon 1938, 84.

${ }^{49}$ Caesarius Arelatensis, Sermo 19, 5, SCh 175, 490-492, PSP 52, 96.

${ }^{50}$ Por. tamże 52, 5, SCh 243, 438-440, PSP 52, 227.

${ }^{51}$ Por. tamże 52, 6, 440-442, SCh 243, PSP 52, 227: „Tymczasem niektóre kobiety, mądre
} 
5. Godne przyjmowanie Komunii św. Biskup Cezary wymaga od małżonków wstrzemięźliwości płciowej przed większymi świętami, w przeciwnym razie Komunia św. przyjęta przez nich obciążałaby ich sumienie ciężkim grzechem.

„Któż [z was] nie potrafi napominać, aby przed nadejściem większych świąt zachowywano nawet w małżeństwie czystość; aby do ołtarza Pańskiego podchodzono ze szczerym i czystym sumieniem? Ponieważ kto przyjmuje komunię bez [wymaganej] czystości, skąd mógł mieć lekarstwo, właśnie tam znajdzie potępienie" ${ }^{, 52}$.

Cezary uważa, że wstrzemięźliwość płciowa w małżeństwie zapewnia godne przyjmowanie Eucharystii. Podkreśla wagę odpowiedniego słownictwa, czystości serca i ciała $^{53}$. Taki sposób postępowania zapewnia świętość i życie wieczne z Chrystusem.

Świętowanie niedzieli i innych uroczystości powinni wierni uszanować przez powstrzymanie się od współżycia płciowego.

„Przede wszystkim, kiedy nadchodzi niedziela, albo inna uroczystość, niech nikt nie współżyje ze swoją żoną. I kiedy kobiety mają okres, to samo należy zachować, zgodnie z tym, co mówi Prorok: «Nie zbliżaj się do żony w okresie jej menstruacji» (Ez 18, 6). Kto zbliża się do żony swojej w okresie jej krwawienia albo nie będzie się chciał powściągnąć w niedzielę i w inne uroczystości, to dzieci wtedy poczęte narodzą się trędowate, chore umysłowo albo nawet opętane przez diabła ${ }^{54}$. Przecież wszyscy trędowaci zwykli się rodzić z ludzi prostych, którzy nie potrafią się opanowywać, a nie z ludzi mądrych, którzy zachowują czystość w dni świąteczne, czy nawet w inne

i chrześcijańskie, gdy ich dzieci chorują, zwykły opowiadać karmicielkom i innym niewiastom i mówić za podszeptem diabła: Ja się w takie i podobne rzeczy nie wdaję, bo w kościele się czyta: «Nie możecie pić z kielicha Pana i z kielicha demonów, nie możecie zasiadać przy stole Pana i przy stole demonów» (1Kor 10, 20-21). Kiedy to powie jakby się wymawiając: Idźcie sobie i róbcie, co chcecie, nie zabraniam wam z kasy brać na wydatki. Ale czy przez takie słowa można uczynić się niewinnym zgubnych zbrodni? Tak jednak nie jest, ponieważ nie tylko matka, jeżeli się na to zgadza, ale i inni, którzy na to przyzwalają, popadają w zbrodnię świętokradztwa. Tak mówi Apostoł: «Nie tylko ci, co je popełniają, ale także ci, co się z nimi zgadzają» (Rz 1, 32). Zarówno mężczyźni, jak i kobiety, jeżeli zechcecie pilnie zwrócić na to uwagę i będziecie usiłowali wiernie unikać i uciekać od wszelkich zasadzek diabła, będziecie mogli ze spokojnym sumieniem wejść do wiecznej szczęśliwości z pomocą naszego Pana Jezusa Chrystusa".

${ }^{52}$ Tamże 1, 12, SCh 175, 248, PSP 52, 25. Por. tamże 44, 3, SCh 243, 330-332, PSP 52, 195; 19, 3, SCh 175, 486-488, PSP 52, 95.

${ }^{53}$ Por. tamże 33, 4, SCh 243, 178-180, PSP 52, 148. Zob. tamże 19, 3, SCh 175, 486-488, PSP 52,95 .

${ }^{54}$ Wiara $\mathrm{w}$ to, że poczęcie dzieci w niedzielę naraża je na nienormalność, była bardzo rozpowszechniona. Grzegorz z Tours (De virtutibus S. Martini episcopi II, 24, ed. B. Krusch, MGH Scriptores rerum Merovingicarum I/2, Hannoverae 1885, 167), opowiada historię kobiety z Biturico (Bourges?), która wydając na świat zniekształcone dziecko (niewidoma niemowa), orzekła płacząc, że poczęła je w nocy z soboty na niedzielę. 
dni. Naprawdę, bracia, jeżeli nierozumne zwierzęta nie schodzą się, jak tylko w pewnych i naturą określonych czasach, to o ileż bardziej ludzie, na obraz Boży stworzeni powinni tego przestrzegać. Lecz to jest gorsze, że są mężowie tak rozpustni lub tak pijani, którzy nie oszczędzają nawet brzemiennych małżonek" $"$.

Biskup Cezary idzie za przekonaniem epoki twierdząc, że dzieci poczęte w niedzielę, uroczystości lub w czasie menstruacji kobiety rodzą się z poważnymi defektami fizycznymi, duchowymi, a nawet opętane przez diabła.

Cezary z Arles łączy przyjmowanie Komunii św. z Modlitwą Pańską a szczególnie z wezwaniem do przebaczenia tym, którzy zawinili. Oznacza to, że do stołu Eucharystycznego trzeba podchodzić bez nienawiści do bliźniego, bowiem Ten, który obecny jest w Komunii, przebaczył wszystkim swoim winowajcom.

„Ilekroć obchodzimy jakieś uroczystości i zamierzamy przyjmować Komunię, zdajecie sobie sprawę, dokąd przystępujemy, i zanim przystąpimy, wiecie, co wpierw zamierzamy powiedzieć w Modlitwie Pańskiej: «Odpuść nam nasze winy, jak i my odpuszczamy naszym winowajcom» (Mt 6, 12). Uczyńcie to i wybaczcie sobie winy, skoro przyjdziecie do tych słów modlitwy. [...] Powiedz sercu twojemu: Nie waż się nienawidzić. Jeżeli dotąd nienawidzisz, powiedz duszy swojej: Nie waż się nienawidzić. [...] Nie chciej nienawidzić, żebyś mnie nie zgubił. «Czemu jęczysz we mnie? Ufaj Bogu» (Ps 41, 6). Smutna jesteś, jęczysz, usychasz ze zgryzoty, nie możesz znieść nienawiści. «Ufaj Bogu». On jest Lekarzem, za ciebie zawisł na krzyżu, a mimo to nie jest mścicielem. Czemuż ty chcesz się mścić? Po to bowiem nienawidzisz, abyś się mógł zemścić. Popatrz na wiszącego na drzewie, jak gotuje ci lekarstwo na twoje słabości z krwi swojej. I jeszcze chcesz się mścić? Popatrz na Chrystusa wiszącego na krzyżu, posłuchaj, jak się modli: «Ojcze, przebacz im, bo nie wiedzą, co czynią» (Łk 23, 34) ${ }^{\prime 56}$.

Biskup Arles uzależnia owocne przyjmowanie Eucharystii od pojednania z bliźnimi.

Cezary kierując się szacunkiem do Eucharystii, uważa, że przyjmować Ją może tylko człowiek posiadający czyste sumienie.

„Zważajcie na to bracia, że kto prosi o pokutę, prosi, by go ekskomunikowano. W konsekwencji, gdy już otrzyma pokutę, ubrany we włosiennicę wyrzucany jest na zewnątrz [kościoła]. Dlatego prosi o ekskomunikowanie go, gdyż uważa się za niegodnego przyjmowania eucharystii Pańskiej. Chce się uczynić obcym dla tego ołtarza, by zasłużyć z czystym sumieniem na dojście do ołtarza, który jest w niebie. Dlatego jako winny i bezbożny chce z wielkiego

${ }^{55}$ Caesarius Arelatensis, Sermo 44, 7, SCh 243, 338-340, PSP 52, 197.

${ }^{56}$ Tamże 35, 1, SCh 243, 194-196, PSP 52, 152. Por. tamże 39, 4, SCh 243, 262-264, PSP 52, 173-174; 73, 2, SCh 330, 190-194. 
szacunku być odsunięty od Ciała i Krwi Chrystusa, aby przez to upokorzenie zasłużyć kiedyś na komunię przy najświętszym ołtarzu"57.

Cezary z Arles zwraca uwagę na niszczącą siłę szatana na wiernych, którzy chcą być wierni Jezusowi Chrystusowi i należycie świętować dzień Pański.

„Diabeł, najdrożsi bracia, zwykł nas atakować zwłaszcza wtedy, kiedy wie, że nie jesteśmy uzbrojeni przeciw niemu duchową bronią; ponieważ nie może nas wygnać fizycznie ze zgromadzenia w kościele, stara się właśnie w kościele, przeszkadzać nam bezowocnymi myślami i zajmować nas próżnymi plotkami, aby móc przez próżne i puste rozmowy, a może nawet złośliwe i brudne myśli, porwać owoc Bożej lektury i lekarstwo modlitwy w ten sposób, że tylko ciałem tkwimy w kościele, a sercem i myślą jesteśmy daleko od oblicza Bożego majestatu. [...] Dlatego najdrożsi bracia, proszę was, stawiajmy opór tym ciężkim niewolom duszy, tak jak możemy, z pomocą Pana, a bezużyteczne historyjki, które nawet, jak wiemy, poza kościołem są szkodliwe, odpędźmy je zwłaszcza w kościele, jako truciznę diabła"58.

Cezary jest przekonany o destrukcyjnej sile oddziaływania diabła na człowieka. Jeśli nawet szatan nie przeszkodzi wiernym w przyjściu do kościoła, to prowokując ich do rozmów i niegodnego zachowania i tak osiąga swój cel. Na nic bowiem nie przydaje się fizyczna obecność w kościele, kiedy serce człowieka nie jest przy Bogu.

„Diabeł dąży nie tyle do zabicia ciała naszego, ale duszy. Dlatego dopuszcza mu Pan Bóg dla naszego wypróbowania dotknąć nasze ciało jakąś słabością, a my później przyzwalamy mu przez używanie amuletów czy frędzelków i przez uciekanie się do zamawiaczy, przez co on zabija naszą duszę. A nam czasem się zdaje, że amulety nam pomogły. Dzieje się tak dlatego, że diabeł widząc, iż przez nasze zezwolenie już duszę naszą śmiertelnie uderzył, przestaje dręczyć chorobą ciało. Wykonujący filakterie, proszący o nie oraz każdy, kto się na nie zgadza, wszyscy stają się poganami, i jeżeli nie będą czynić godnej pokuty, nie mogą ujść kary. Wy natomiast, bracia, szukajcie uzdrowienia u Chrystusa, bo On jest prawdziwym światłem. Udajcie się do kościoła, namaszczajcie się olejem świętym, przyjmujcie Eucharystię Chrystusa. Jeżeli to uczynicie, odzyskacie nie tylko zdrowie ciała, ale i zdrowie duszy otrzymacie" 59 .

Biskup Cezary wyjaśnia sposób działania szatana na ludzi w przypadku stosowania przez nich amuletów. Szatan mając w posiadaniu duszę człowieka, przestaje dręczyć ciało chorobą. Nie można dać się zwodzić diabłu i jednocześnie po uzyskanie zdrowia duszy i ciała udawać się do kościoła, przyjmo-

\footnotetext{
${ }^{57}$ Tamże 67, 2, SCh 330, 130-132. Por. tamże 44, 6, SCh 243, 336-338, PSP 52, 197.

${ }^{58}$ Tamże 77, 7, SCh 330, 234-236.

${ }^{59}$ Tamże 50, 1, SCh 243, 418-420, PSP 52, 221.
} 
wać sakrament namaszczenia chorych i Eucharystię. Spożywanie Ciała i Krwi Pańskiej kłóci się z jakimikolwiek związkami z demonami ${ }^{60}$.

Niegodne zachowanie w kościele i złe prowadzenie się to, zdaniem Cezarego, oddawanie czci szatanowi i skazywanie siebie na potępienie.

„Są także inni, którzy tylko po to pragną przyjść na święta narodzin męczenników, aby siebie gubić i innych gorszyć piciem, tańcem, śpiewaniem wstrętnych piosenek, prowadzeniem korowodów i diabelskim podskakiwaniem $^{61}$. Ci, którzy powinni czynić dzieła Chrystusa, odważają się pełnić posługę diabła. Tych nie miłość Chrystusa, ale miłość rozwiązłości zwykle przyciąga na uroczystości, ponieważ nie dla przykładu dobrych uczynków, nie po lekarstwo dla wiary, ale gromadzą się, aby przygotować [sobie] truciznę i sidła diabelskie. Chcący ich oglądać lub naśladować skazują swoją duszę na wieczną karę" ".

Cezary zachęca wiernych do modlitwy w kościele, może ona bowiem człowieka wyrwać z sideł piekła. Jest przekonany, że kto milczy w kościele lub zajmuje czym innym niż modlitwa poddaje się pod działanie diabła. Modlitwa i skupiona postawa wiernych w kościele są, zdaniem Cezarego, skuteczną bronią przeciw szatanowi ${ }^{63}$. Modlitwa i właściwe zachowanie w kościele świadczy też o przynależności człowieka do Chrystusa. Brak modlitwy, śpiewu na ustach, pokazuje, że człowiek jest na usługach nieprzyjaciela Chrystusa i rodzaju ludzkiego. Cezary przypomina ewangeliczną zasadę, która mówi, że człowiek napełniony Bogiem może wydobywać z serca dobro. Jeśli człowiek się nie modli, nie słucha słowa Bożego, zajmuje błahymi sprawami w kościele, nie wprowadza do serca Chrystusa i nie może później z serca, jak ze skarbca wydobyć niczego dobrego, gdyż wcześniej nie posiadł dobra, lecz $\mathrm{zło}^{64}$.

$$
* * *
$$

Biskup Cezary uświadamia wiernym powierzonym jego pieczy wagę dnia Pańskiego i dni świątecznych. Uczęszczanie do kościoła ma wymiar społeczny, odróżnia w sposób jednoznaczny wyznawców Chrystusa od pogan. Cezaremu zależy na tym, aby chrześcijanie systematycznie i regularnie uczęszczali na nabożeństwa w kościele, aby dbali o punktualność i nie wychodzili ze świątyni przed zakończeniem Mszy św. Cezary jako doświadczony duszpasterz zwraca wiernym uwagę na ich postawę w kościele. Za wzór stawia ewangelicznego celnika, który był uniżony przed Bogiem zarówno ciałem (skłon), jak

\footnotetext{
${ }^{60}$ Por. tamże 54, 5, SCh 243, 458-460, PSP 52, 233.

${ }^{61}$ Por. tamże 13, 4, SCh 175, 422-424, PSP 52, 76.

${ }^{62}$ Tamże 55, 2, SCh 243, 468, PSP 52, 235.

${ }^{63}$ Por. tamże 80, 2, SCh 330, 256.

${ }^{64}$ Por. tamże 80,3 , SCh 330, 256-258.
} 
i duchem (pokora serca). Właściwa postawa w kościele jest wyrazem wiary lub jej zaprzeczeniem, dlatego biskup Arles przypomina o godnym zachowaniu, domagając się w świątyni ciszy. Zwraca także uwagę na ubiór przychodzących do kościoła. Wierny musi mieć świadomość, że w czasie Mszy św. spotyka się z Bogiem i dlatego ma zadbać o czystość swego sumienia i czystość ubrania.

Cezary pokazuje różnicę pomiędzy chrześcijaństwem i pogaństwem. Chrześcijanie świętują niedzielę, poganie czwartek na cześć bożka Jowisza. Domaga się od wiernych zaniechania prowadzenia spraw sądowych w niedzielę i powstrzymania od wykonywania pracy. Podkreśla natomiast potrzebę pełnienia dobrych uczynków wobec bliźnich, szczególnie jałmużny oraz poświęcania dużej ilości czasu na czytanie słowa Bożego.

Biskup Arles w centrum dnia Pańskiego stawia Eucharystię. Wierni mają przynosić do kościoła dary do konsekracji, które później są rozdzielane wszystkim. Poucza, że Eucharystia jest prawdziwym Ciałem i Krwią Chrystusa. Wykazuje, że Komunia św. jest lekarstwem dla człowieka - dla jego ciała i dla jego duszy. Stąd jego troska, aby wierni przyjmowali Eucharystię z czystym sercem. Naucza, że małżonkowie przed przystąpieniem do Komunii św. mają zachować przynajmniej na trzy dni przed jej przyjęciem wstrzemięźliwość seksualną. Cezary uważa, że niewierność Chrystusowi jest zwróceniem serca ku szatanowi, co uniemożliwia przystępowanie do stołu Pańskiego. Koniecznym warunkiem, by móc przyjąć Eucharystię jest przebaczenie bliźniemu.

\section{THE LORD'S DAY IN TEACHING OF ST. CAESAR OF ARLES IN THE LIGHT OF STUDY ON HIS SERMONS FOR PEOPLE}

\section{(Summary)}

Speaking about the Lord's Day, saint Caesar of Arles ( $†$ 543) explains to the faithful the importance of this day and other religious holidays. Going to church has a social dimension and clearly distinguishes Christians from Pagans. Bishop of Arles attaches much importance to the fact that Christians systematically and regularly attend church services, care about punctuality and do not leave the church before the end of the Mass. St Caesar, being an experienced pastor, instructs the faithful how to behave in the church. He shows the difference between Christianity and Paganism. Christians celebrate on Sunday, Pagans on Thursday in honour of Jupiter. He asks the faithful not to conduct any court cases on Sunday and abstain from work. Bishop of Arles put the Eucharist in the centre of the Lord's Day. He teaches that the Eucharist is true Body and Blood of Christ. He points out that the Holy Communion is like medicine for a human being, for his body and his soul, hence the concern of the Bishop so that faithful receive the 
Eucharist with a pure heart. A necessary condition for receiving of the Eucharist is to forgive a neighbour.

Słowa kluczowe: dzień Pański, chrześcijanin, poganin, Msza św., sprawy sądowe, praca, Eucharystia, przebaczenie.

Key words: The Lord's Day, Christian, Pagan, Holy Mass, court cases, work, the Eucharist, forgiveness. 